\title{
Effect of High and Low Density Lipoproteins on Proliferation of Cultured Bovine Vascular
}

\section{Endothelial Cells}

\author{
Jean-Pierre Tauber, Jannie Cheng, and Denis Gospodarowicz, Cancer Research \\ Institute and Departments of Medicine and Ophthalmology, University of \\ California Medical Center, San Francisco, California 94143
}

\begin{abstract}
A B S T R A C T Bovine vascular endothelial cells maintained on dishes coated with an extracellular matrix and exposed to medium supplemented with lipoproteindeficient serum (LPDS) require the presence of lipoprotein to proliferate optimally. High density lipoprotein (HDL) seeins to be the major factor involved in the proliferation of vascular endothelial cells. This is mostly due to its lack of toxicity when added at high concentration, as well as to its nondependence on LPDS to exhibit its mitogenic properties. Therefore, HDL at physiological concentrations $(1,000-1,500 \mu \mathrm{g}$ protein $/ \mathrm{ml}$ ) can fully replace serum. Low density lipoprotein, unlike HDL, has a biphasic effect. Although mitogenic for vascular endothelial cells when added at low concentration, once physiological concentrations are reached it becomes toxic for the cells. Moreover, and in contrast with HDL, the mitogenic effect of low density lipoprotein was found to be a function of the LPDS concentration to which cultures were exposed.

The substrate upon which cultures are maintained has been found to be an important factor if a mitogenic effect of HDL is to be observed. When maintained on plastic, cells proliferate poorly in response to HDL unless fibroblast growth factor is added to the medium. In contrast, when maintained on extracellular matrix, an optimal growth rate is induced by HDL, even in the absence of fibroblast growth factor. This suggests that, in vivo, the integrity of the basement membrane upon which endothelial cells rest and migrate is an important factor in determining the cells' response to lipoproteins present in plasma.
\end{abstract}

\section{INTRODUCTION}

Previous studies have shown that low density bovine vascular endothelial cells seeded at either clonal or low

Received for publication 28 April 1980 and in revised form 10 June 1980. cell density on dishes coated with an extracellular matrix $(\mathrm{ECM})^{1}$ no longer require fibroblast growth factor (FGF) in order to proliferate actively (1). Exposure to medium supplemented with either plasma or serum is enough to insure optimal growth rate of the cultures. This suggests that the cells now respond to one or more factors present in plasma as well as in serum (1), provided that they are maintained on ECM-coated dishes.

Among the plasma factors that could be held directly or indirectly responsible for the proliferation of vascular endothelial cells are the high density lipoproteins (HDL) and the low density lipoproteins (LDL). Previous studies have shown that both LDL and HDL can interact specifically with vascular endothelial cells $(2-5)^{2,3}$ and others have shown that LDL could be mitogenic for vascular smooth muscle cells and dermal fibroblasts when added to lipoprotein-deficient serum (LPDS) (6-8) or to serum from a beta lipoproteinemic subjects (9). Likewise, in the case of cells that have a limited ability to make cholesterol de novo or in the case of cells maintained in the presence of compounds such as compactin, which totally inhibit their ability to make cholesterol, addition of LDL to the medium leads to resumption of cell proliferation (10). In that case, LDL could act by providing an exogenous source of cholesterol to the cells, thereby obviating the block in

\footnotetext{
${ }^{1}$ Abbreviations used in this paper: CS, calf serum; DMEM, Dulbecco's modified Eagle's medium; ECM, extracellular matrix; FGF, fibroblast growth factor; HDL, high density lipoprotein; LDL, low density lipoprotein; LPDS, lipoprotein-deficient serum; PPPS, platelet-poor plasma serum; WBS, whole blood serum.

${ }^{2}$ Tauber, J-P., D. Goldminz, I. Vlodavsky, and D. Gospodarowicz. Interaction of high density lipoprotein with cultured vascular endothelial cells. Submitted for publication.

${ }^{3}$ Tauber, J-P., I. Vlodavsky, D. Goldminz, and D. Gospodarowicz. Up-regulation in vascular endothelial cells of high density lipoprotein receptor sites induced by 25-hydroxycholesterol. Submitted for publication.
} 
cholesterol synthesis resulting from the presence of the inhibitor in the medium (10).

In the present study, we have compared the respective mitogenic activities of serum, plasma, and LPDS on cultured vascular endothelial cells maintained on dishes coated with an EC.M. We have also compared the mitogenic effects of HDL and LDL on vascular endothelial cell cultures exposed to LPDS or to serum-fiee medium. Our results indicate that, although both HDL and LDL are mitogenic for cultured vascular endothelial cells, HDL may be the physiological agent responsible for the control of proliferation of that tissue.

\section{METHODS}

Materials. FGF was purified as previously described from bovine brains (11). The 675 fraction was used in the present study (11). Dulbecco's modified Eagle's medium (DMEM, H-16) was obtained from Gibco Laboratories, Grand Island Biological Co., Grand Island, N. Y. Calf serum and fetal calf serum were obtained from Irvine Serum Co., Irvine, Calif Tissue culture dishes were from Falcon Labware, Dis. of Becton, Dickinson \& Co., Gentamycin, Oxnard, Calif.; from Schering Corp., Kenilworth, N. J.; and Fungizone, from E. R. Squibb \& Sons, Princeton, N. J.

Preparation of plasma and serum. Human plasma and serum were prepared as described by Ross et al. $(12,13)$ Briefly, blood was drawn into plastic syringes containing $3.8 \%$ sodium citrate (1 vol citrate to $10 \mathrm{vol}$ blood). The blood was then recalcified with $1 . \mathrm{M} \mathrm{CaCl}_{2}$ to a final concentration of 14 $\mu \mathrm{mol} / \mathrm{ml}$ and allowed to clot at room temperature for $2 \mathrm{~h}$. The clotted blood was then centrifuged at $2,000 \mathrm{~g}$ for $15 \mathrm{~min}$ at $4^{\circ} \mathrm{C}$. The serum or whole blood serum (WBS) was decanted from the clots and respun $(22,000 \mathrm{~g})$ for $30 \mathrm{~min}$ at $4^{\circ} \mathrm{C}$. The serum was dialyzed (Spectrapor-1, molecular weight cutoff 6,000 $8,(0) 0)$ against Ringer's solution at $4^{\circ} \mathrm{C}$ for $24 \mathrm{~h}$. The serum was then filtered on a $0.2-\mu \mathrm{m}$ Millipore filter (Millipore Corp., Bedford, Mass.) and stored at $-70^{\circ} \mathrm{C}(13)$.

Platelet-poor plasma serum (PPPS) was prepared by drawing the blood into rechilled $\left(4^{\circ} \mathrm{C}\right)$ citrated syringes. All subsequent steps other than the recalcification and clotting were carried out at $4^{\circ} \mathrm{C}$. The blood was spun $(2,000 \mathrm{~g}$ for $15 \mathrm{~min})$, and the resulting plasma was pipetted off and respun $(22,000 \mathrm{~g}$ for $30 \mathrm{~min}$ ). At this point the platelet-poor plasma was pooled and $1.0 . \mathrm{I} \mathrm{CaCl}_{2}$ was added to a final concentration of 20 $\mu \mathrm{mol} / \mathrm{ml}$. Following a $2-\mathrm{h}$ incubation at $37^{\circ} \mathrm{C}$, the plasma was then spun $(22,000 \mathrm{~g}$ for $30 \mathrm{~min})$ to remove the fibrin clot and the supernate was dialyzed against Ringer's solution at $4^{\circ} \mathrm{C}$ for $24 \mathrm{~h}$. Following dialysis, the plasma was respun $(22,000 \mathrm{~g}$ for $30 \mathrm{~min})$. The supernate was then filtered on a $0.2-\mu \mathrm{m}$ Millipore filter and frozen at $-70^{\circ} \mathrm{C}(13)$. Protein concentration was determined by the modification of Maxwell et al. (14) of the method of Lowry et al. (15). Final protein concentrations were adjusted to $60 \mathrm{mg} / \mathrm{ml}$ by diluting plasma or serum with Ringer's solution.

Preparation of LDL, HDL, and LPDS. Human LDL (1.019 $\left.<d<1.063 \mathrm{~g} / \mathrm{cm}^{3}\right)$, HDL $\left(1.07<d<1.210 \mathrm{~g} / \mathrm{cm}^{3}\right)$, and LPDS $\left(d>1.25 \mathrm{~g} / \mathrm{cm}^{3}\right)$ were obtained from human plasma by differential ultracentrifugal flotation (16). To remove contaminating plasma proteins further, the LDL and HDL preparations were washed by recentrifugation in solutions of densities 1.063 and $1.210 \mathrm{~g} / \mathrm{cm}^{3}$, respectively. Protein concentrations were determined as described above. LPDS protein concentration was adjusted to $60 \mathrm{mg} / \mathrm{ml}$ by dilution with Ringer solution.
The purified HDL and LDL preparations were analyzed by double immunodiffusion to determine the degree of cross-contamination of the HDL and LDL preparations. ${ }^{2,3}$ When HDL or LDL preparations were analyzed by double immunodiffusion, $0.2 \mu \mathrm{g}$ of HDL protein gave a single precipitin line against rabbit anti-human $\alpha-1$ lipoprotein (CalbiochemBehring Corp., American Hoechst Corp., San Diego, Calif.). In the case of LDL, no precipitin line could be observed even at a 50)-fold higher protein concentration (100 $\mu \mathrm{g}$ protein). Likewise, LI)L ( $0.2 \mu \mathrm{g}$ protein) gave a single precipitin line when tested against rabbit anti-human $\beta$-lipoprotein (N. L. Cappel Laboratories Inc., Cochranville, Pa.), whereas HDL at 50() -fold higher protein concentration did not give a precipitin line. These results demonstrate that HDL preparations contained $<0.2 \% \mathrm{LDL}$, if any at all, and vice versa. ${ }^{2.3}$ To eliminate the possibility of a contamination by plasma proteins, the purity of the LDL and HDL preparations was analyzed by slab gel electrophoresis (10-18\% and 5-18\%, respectively, exponential polyacrylamide gel gradient containing $0.1 \%$ sodium dodecyl sulfate) with or without prior delipidation with tetramethyl urea., ${ }^{2,4}$ When the electrophoretic patterns of HDL and LDL preparations were compared with that of plasma or LPDS, no obvious contamination by plasma proteins was observable.

Cell culture conditions. Cultures of bovine corneal endothelial cells were established from steer eyes as already described $(17,18)$. Stock cultures were maintained on tissue culture dishes in DMEM supplemented with $10 \%$ fetal calf serum, $5 \%$ calf serum (CS), $50 \mu \mathrm{g} / \mathrm{ml}$ Gentamycin, and $2.5 \mu \mathrm{g} / \mathrm{ml}$ Fungizone. FGF $(100 \mathrm{ng} / \mathrm{ml})$ was added every other day until the cells were nearly confluent. Plastic dishes coated with an EC.M produced by comeal endothelial cells were prepared as already described $(1,19,20)$. Cultures of bovine vascular endothelial cells were established from adult aortic arch as already described (21-23). Stock cultures were maintained in the presence of DMEM supplemented with $10 \% \mathrm{CS}, 50 \mu \mathrm{g} / \mathrm{ml}$ Gentamycin, $2.5 \mu \mathrm{g} / \mathrm{ml}$ Fungizone, and FGF $(100 \mathrm{ng} / \mathrm{ml})$ added every other day. Stock cultures were passaged weekly at a split ratio of 1:64.

Cell seeding in the presence of serum. Cell monolayers from stock plates were dissociated by exposure $\left(2-3 \mathrm{~min}, 24^{\circ} \mathrm{C}\right)$ to a solution containing $0.9 \% \mathrm{NaCl}, 0.01 \mathrm{M}$ sodium phosphates (pH 7.4), $0.05 \%$ trypsin, and $0.02 \%$ EDTA (STV solution, Difco Laboratories, Detroit, Mich.). When cells rounded up, they were resuspended in DMEM supplemented with $10 \%$ CS to inhibit further proteolysis. The cell suspension was then spun down and the cell pellet resuspended in DMEM supplemented or not with either $10 \% \mathrm{CS}$ or $5 \%$ LPDS. An aliquot of the cell suspension was then counted in a Coulter counter (Coulter Electronics Inc., Hialeah, Fla.) and cells were distributed at an initial cell density of $2 \times 10^{4}$ cells/35-mm dish as described below.

Cell growth measurement and culture lifetime determination. For cell growth measurements, cells were seeded, as described above, at an initial density of $2 \times 10^{4}$ cells $/ 35-\mathrm{mm}$ dish on either plastic dishes or dishes coated with an ECM. When cultures were exposed to FGF, it was added every other day at a concentration of $100 \mathrm{ng} / \mathrm{ml}$. In the case of cultures exposed to HDL or LDL, the lipoproteins were added once (day $0)$ at the indicated concentrations. Triplicate plates were trypsinized and counted with a Coulter counter every other day. Morphological appearance of the cultures was analyzed by phase-contrast microscopy, and pictures were taken once the cultures maintained on ECM or plastic became confluent. In the

${ }^{4}$ Tauber, J-P., J. Cheng, and D. Gospodarowicz. High density lipoproteins and the growth of vascular endothelial cells in serum-free medium. Submitted for publication. 
case of cultures exposed to various concentrations of human serum or plasma, seeding was done in the presence of $10 \% \mathrm{CS} .6 \mathrm{~h}$ later, a set of triplicate plates was trypsinized and cells were counted to determine the plating efficiency. Plates were then washed twice with DMEM and $2 \mathrm{ml}$ of DMEM containing the appropriate concentration of serum or plasma was then added to the plates. In the case of cultures exposed to different concentrations of LPDS, a similar procedure was used, except that cells were plated initially in 5\% LPDS. $6 \mathrm{~h}$ later, plates were washed as described above and medium containing the various concentrations of LPDS was then added to the plates. When cultures were to be maintained in serum-free medium, seeding of the cultures was done in the presence of DMEM supplemented with $10 \%$ CS. $8 \mathrm{~h}$ later, the plates were washed twice with DMEM alone, and DMEM supplemented with various concentrations of either HDL or LDL was then added to the plates. Culture lifetime determinations were performed as already described (1). ${ }^{4}$

\section{RESULTS}

Comparison of the proliferative rates of low density vascular endothelial cell cultures as a function of the substrata upon which cells are attached (ECM vs.plastic) and biological fluid to which they are exposed (plasma vs. serum vs. LPDS). The rate of proliferation of low density cultures $\left(20\right.$ cells $\left./ \mathrm{mm}^{2}\right)$ maintained on plastic was a function of the plasma or serum concentration to which cultures were exposed. After $6 \mathrm{~d}$, an 8- and 10-fold increase in cell density was observed for cultures exposed to 5\% plasma or serum, respectively (Fig. 1). Higher plasma or serum concentrations (10\%) were toxic for the cells. When cultures maintained on plastic were exposed to increasing concentrations of LPDS (from 0.5 to $5 \%$ ), their final cell density after $6 \mathrm{~d}$ was in all cases lower than the initial seeding density, indicating that cells did not survive under these conditions (Fig. 1).

When cultures maintained on ECM-coated dishes were exposed to increasing concentrations of plasma or serum (from 0.5 to $10 \%$ ), their cell density after $6 \mathrm{~d}$ was four- to five-fold higher than when maintained under similar conditions on plastic. No toxic effect was observed at high (10\%) plasma or serum concentrations (Fig. 1). When cultures maintained on ECM were exposed to LPDS, the cells hardly proliferated. They did survive quite well, however, since even at low concentration $(0.5 \%)$ of LPDS the cell density did not vary over a 6 -d period (Fig. 1).

These results therefore suggest $(a)$ that the proliferative response of vascular endothelial cells to one or more mitogenic factors present in human plasma or human serum is improved when cells are maintained on an ECM rather than on plastic; (b) that lipoproteins, which are the missing components in LPDS, could play a role in the proliferation of vascular endothelial cells, inasmuch as cells maintained on ECM and exposed to optimal concentrations of LPDS hardly proliferate, while when exposed to human plasma they proliferate

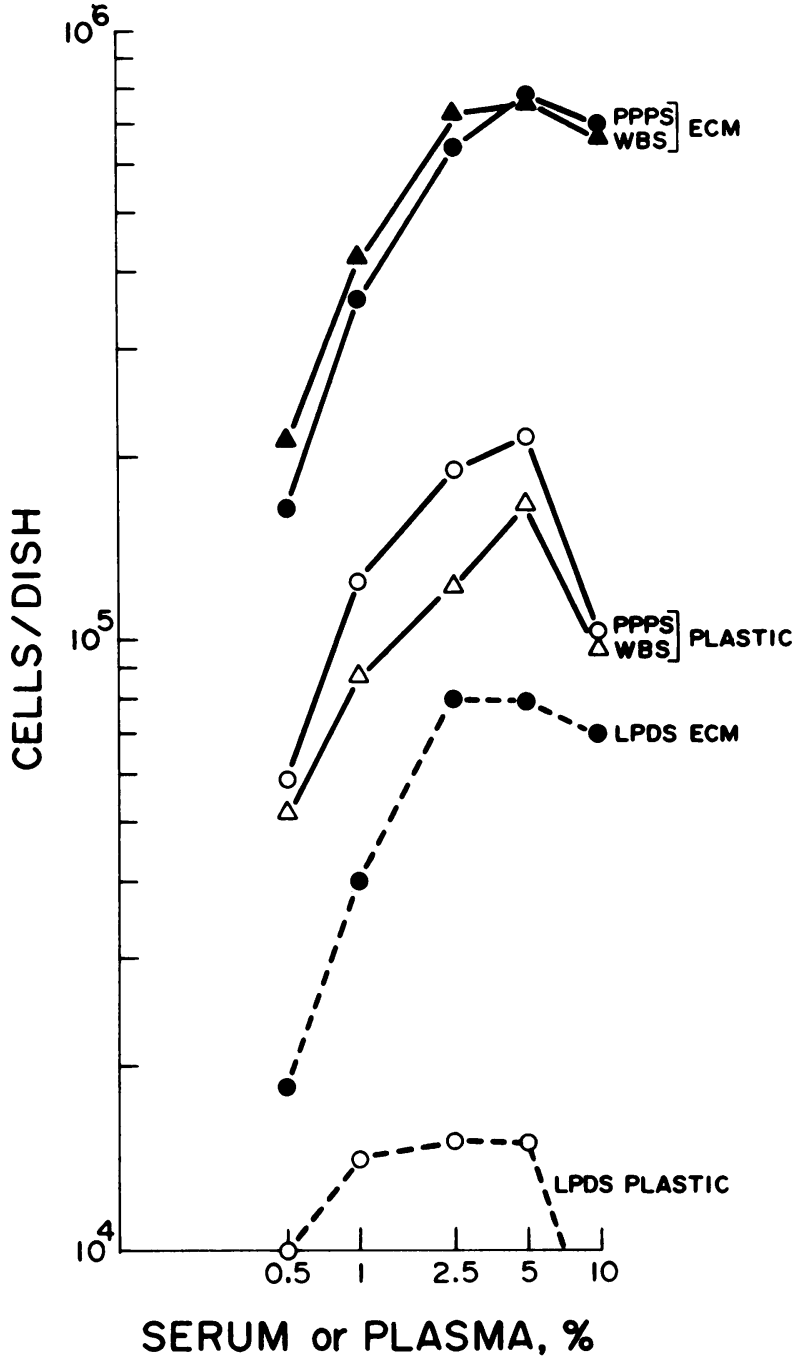

FIGURE 1 Proliferation of bovine vascular endothelial cells maintained on plastic or on ECM and exposed to different concentrations of plasma, serum, or LPDS. Vascular endothelial cells were seeded at $2 \times 10^{4}$ cells $/ 35-\mathrm{mm}$ dish on either plastic (open symbols) or ECM-coated dishes (filled symbols) and maintained in the presence of DMEM supplemented with either $10 \%$ CS or 5\% LPDS. After $6 \mathrm{~h}$, the medium was removed and the cultures washed twice with DMEM. Cells incubated in DMEM supplemented with $10 \%$ CS were then exposed to DMEM supplemented with increasing concentrations, ranging from 0.5 to $10 \%$, of PPPS (circles solid lines) or WBS (triangles solid lines). Cells exposed to DMEM supplemented with 5\% LPDS were then exposed to increasing concentrations of LPDS ranging from 0.5 to $10 \%$ (circles and dashed lines). After $6 \mathrm{~d}$ the cultures were trypsinized and counted.

actively; $(c)$ that in order to test the hypothesis that cells exposed to LPDS require lipoproteins to proliferate actively, one has to maintain the cultures on ECM-coated dishes, since when cells are maintained on plastic and exposed to LPDS, they do not survive. 
Comparison of the effects of $H D L$ and $L D L$ on the rate of proliferation of low density vascular endothelial cell cultures maintained in the presence of medium supplemented with LPDS. To test the hypothesis that lipoproteins promote the proliferation of vascular endothelial cells, low density cultures $\left(20\right.$ cells $/ \mathrm{mm}^{2}$ ) maintained on dishes coated with an ECM were exposed to medium supplemented with $10 \%$ LPDS alone, $10 \%$ LPDS and $200 \mu \mathrm{g}$ protein $/ \mathrm{ml}$ of LDL, or $10 \%$ LPDS and $500 \mu \mathrm{g}$ protein $/ \mathrm{ml}$ of $\mathrm{HDL}$ (Fig. 2). In the presence of LPDS alone, cultures proliferated with an average doubling time of $55 \mathrm{~h}$. After $6 \mathrm{~d}$ they stopped proliferating, reaching a final cell density of 90 cells $/ \mathrm{mm}^{2}$. In contrast, when cultures were exposed to either HDL or LDL, their average doubling time during their logarithmic growth phase became much shorter $(16 \mathrm{~h})$, and cultures became confluent $\left(900-1,000\right.$ cells $\left./ \mathrm{mm}^{2}\right)$ within $6 \mathrm{~d}$. The final cell density of the cultures was higher when they were exposed to HDL than to LDL, but the difference was small $(20 \%)$. This therefore demonstrates that addition of either

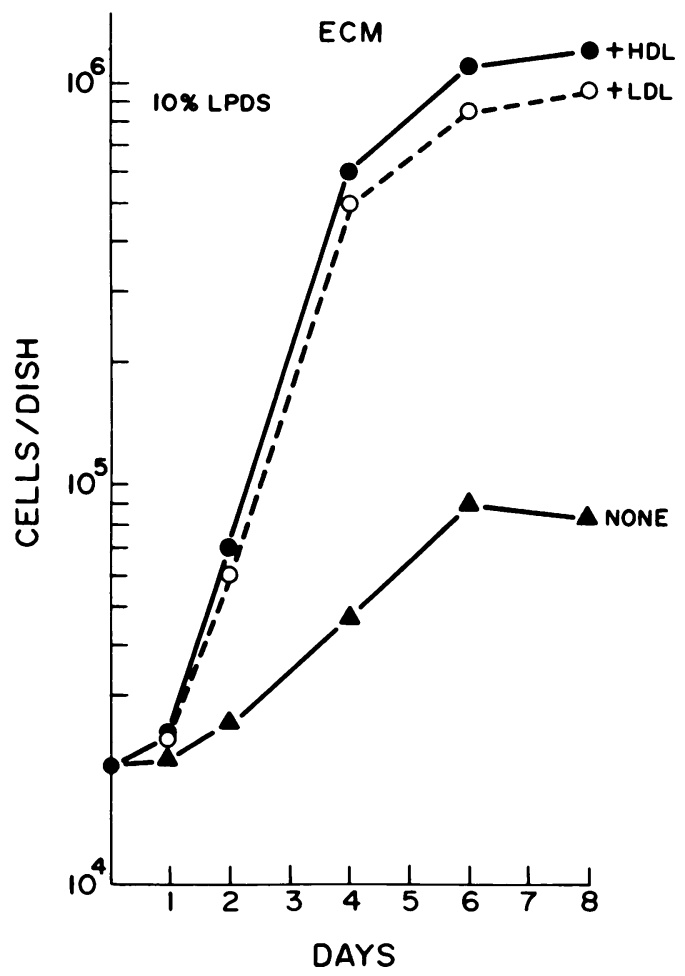

Figure 2 Effects of HDL and LDL on the rate of proliferation of bovine vascular endothelial cells exposed to medium supplemented with high concentration of LPDS. Vascular endothelial cells were seeded at $2 \times 10^{4}$ cells/35-mm dish on ECM-coated dishes and exposed to DMEM supplemented with $10 \%$ LPDS $(6 \mathrm{mg}$ proteins $/ \mathrm{ml})$ alone $(\boldsymbol{\Delta})$, with $10 \%$ LPDS and $500 \mu \mathrm{g}$ protein $/ \mathrm{ml}$ of HDL $(\bullet)$, or with $10 \%$ LPDS and 200 $\mu \mathrm{g}$ protein $/ \mathrm{ml}$ of LDL (O). Every other day, triplicate plates representing each condition were trypsinized and counted.
HDL or LDL to vascular endothelial cell cultures exposed to $10 \%$ LPDS can lead to active cell proliferation.

Effect of increasing concentrations of $H D L$ and $L D L$ on the proliferation of vascular endothelial cells exposed to medium supplemented with either a low $(0.5 \%)$ or a high (5\%) concentration of LPDS. When cells were exposed to low (0.5\%) LPDS concentration (Fig. 3A), addition of HDL at concentrations ranging from 10 to $1,000 \mu \mathrm{g}$ protein $/ \mathrm{ml}$ stimulated their proliferation, and saturation was observed at 500-1,000 $\mu \mathrm{g}$ protein $/ \mathrm{ml}$. The morphological appearance of cultures exposed to increasing concentrations of HDL is shown in Fig. 4A-D. Although when exposed to concentrations ranging from 50 to $100 \mu \mathrm{g}$ protein $/ \mathrm{ml}$, cultures were still sparse $\left(450\right.$ cells $\left./ \mathrm{mm}^{2}\right)($ Fig. $4 \mathrm{~A})$ or subconfluent $\left(750\right.$ cell $\left.\mathrm{s} / \mathrm{mm}^{2}\right)$ (Fig. $4 \mathrm{~B}$ ) after $6 \mathrm{~d}$, concentrations of $250-500 \mu \mathrm{g}$ protein $/ \mathrm{ml}$ led to confluence $\left(900-1,000\right.$ cells $\left./ \mathrm{mm}^{2}\right)$. The cultures were then composed of tightly packed, small, and nonoverlapping cells which formed a monolayer (Fig. 4C and D). When the effect of increasing concentrations of LDL on cell proliferation was analyzed, LDL was found to stimulate cell proliferation when added at concentrations of $10-100 \mu \mathrm{g}$ protein $/ \mathrm{ml}$. At higher concentrations, it became cytotoxic (Fig. 3A). The morphological appearance of cultures exposed to various LDL concentrations is shown in Fig. 4E-H. Because of the cytotoxic effect of LDL at high concentration (Fig. 4H), cells only responded to it when exposed to low LDL concentration (Fig. 4E-G), but in no case did the cultures become confluent within $6 \mathrm{~d}$. The maximum increase in cell density caused by the addition of LDL was therefore fivefold lower than when HDL was present (Fig. 3A).

A similar observation was made in the case of cultures exposed to high (5\%) concentration of LPDS. Addition of HDL at concentrations ranging from 5 to $1,000 \mu \mathrm{g}$ protein $/ \mathrm{ml}$ stimulated cell growth, and the effect was nearly maximal at physiological concentrations of HDL (i.e., $500-1,000 \mu \mathrm{g}$ protein $/ \mathrm{ml}$, Fig. 3B). In contrast, although addition of low concentrations (5 to 50-100 $\mu \mathrm{g}$ protein $/ \mathrm{ml}$ ) of LDL resulted in a faster growth rate of the cultures than when similar concentrations of HDL were added, LDL concentrations above $250 \mu \mathrm{g}$ protein $/ \mathrm{ml}$ killed the cells (Fig. 3B). This was reflected by the rapid decrease in final cell density of the cultures exposed to concentrations of LDL $>250 \mu \mathrm{g}$ protein $/ \mathrm{ml}$.

Therefore, at either low or high LPDS concentration, HDL promotes cell proliferation and is not toxic, even when present at high concentration $(2,000 \mu \mathrm{g}$ protein/ ml, Table I). In contrast, although LDL promotes cell proliferation at low concentrations, a toxic effect is observed when high concentrations are reached. This effect is more pronounced in cultures exposed to low than to high LPDS concentrations.

Effect of increasing concentrations of LPDS on the proliferative response of vascular endothelial cell cul- 


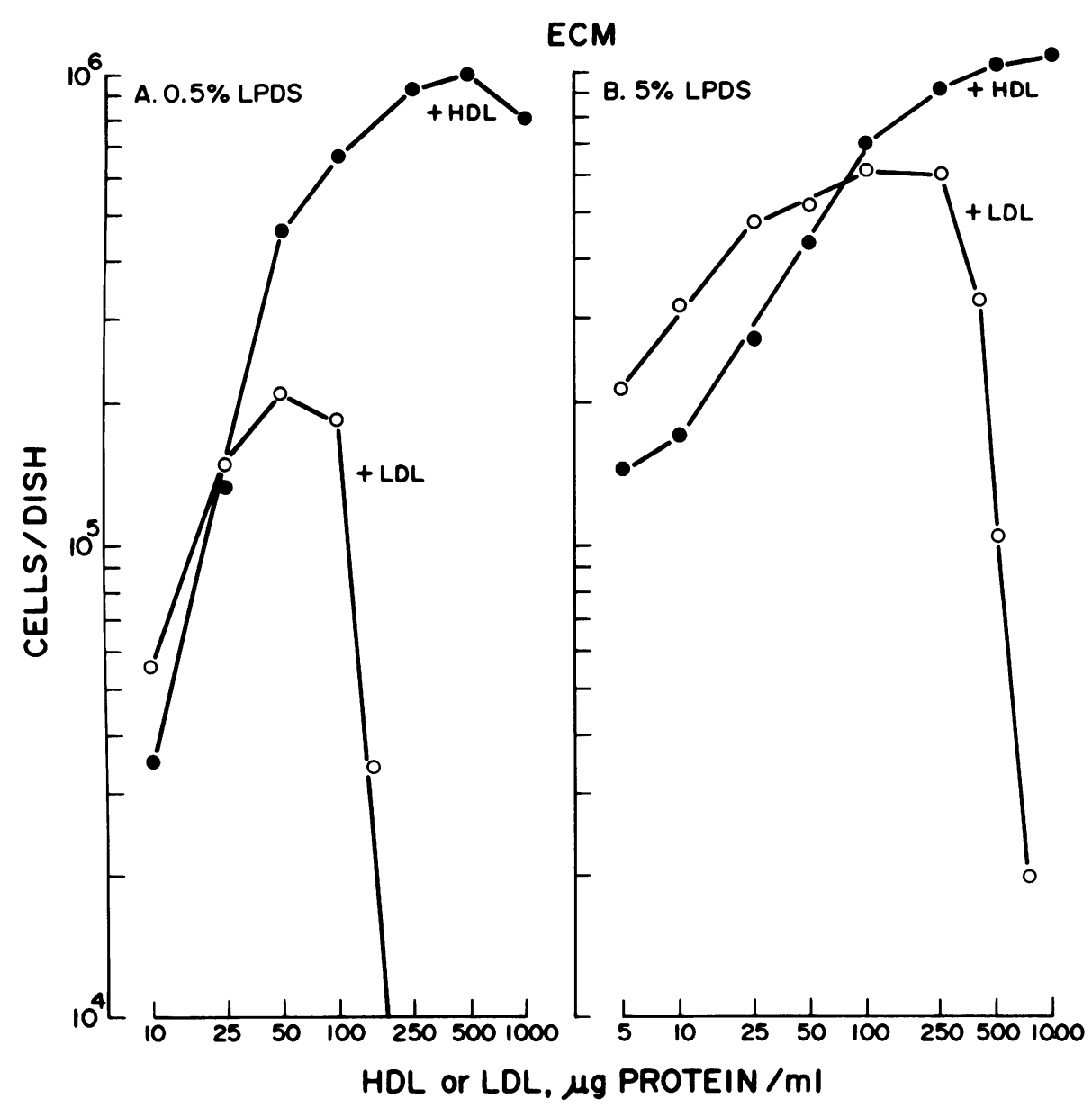

FIGURE 3 Effect of increasing concentrations of HDL or LDL on the proliferation of bovine vascular endothelial cells exposed to medium supplemented with low concentration (A) or high concentrations (B) of LPDS. Vascular endothelial cells were seeded at $2 \times 10^{4}$ cells $/ 35-\mathrm{mm}$ dish on ECM-coated dishes. Cultures were exposed to DMEM supplemented with (A) $0.5 \%$ LPDS (0.3 $\mathrm{mg}$ protein $/ \mathrm{ml}$ ) or (B) $5 \%$ LPDS (3 $\mathrm{mg}$ protein $/ \mathrm{ml}$ ) containing increasing concentrations (ranging from 10 to $1,000 \mu \mathrm{g}$ protein/ml) of HDL (O) or increasing concentrations (ranging from 10 to $700 \mu \mathrm{g}$ protein/ml) of LDL (O). On day 6 , cell cultures were trypsinized and counted.

tures exposed to constant concentration of either $L D L$ or HDL. Because high concentrations of LPDS seem to protect the cells against the toxic effect of high concentrations of LDL, the mitogenic response of vascular endothelial cell cultures exposed to constant concentrations of LDL or HDL as a function of increasing concentrations (from 0.5 to $10 \%$ ) of LPDS has been analyzed. As shown in Fig. 5, HDL at a concentration of $500 \mu \mathrm{g}$ protein $/ \mathrm{ml}$ maximally stimulated low density cultures $\left(20\right.$ cells $\left./ \mathrm{mm}^{2}\right)$ to proliferate, regardless of whether cultures were maintained in low $(0.5 \%)$ or high (10\%) concentrations of LPDS. In contrast, addition of LDL at a concentration of $200 \mu \mathrm{g}$ protein $/ \mathrm{ml}$ resulted either in cell death or in a lower rate of cell proliferation for cultures maintained in either 0.5 or $1 \%$ LPDS (Fig. 5). A small stimulatory effect (2.8-fold) was ob- served at an LPDS concentration of $2.5 \%$ (Fig. 5), and it was only when cultures were exposed to high LPDS concentration (either 5 or $10 \%$ ) that LDL was clearly mitogenic (Fig. 5). This demonstrates that HDL is mitogenic, but not toxic, for vascular endothelial cells, and that its effect is independent of the concentration of LPDS to which cells are exposed. In contrast, LDL can be either mitogenic or toxic for the cells. This depends on the LPDS concentration as well as on the concentration of LDL to which cultures are exposed.

Effect of HDL on the proliferation of vascular endothelial cell cultures exposed to LDL and maintained either in the presence of low (0.5\%) or high (5 or 10\%) LPDS concentrations or in LPDS-free medium. Cultures exposed to high concentrations of LDL and maintained on ECM-coated dishes in LPDS-supplemented 


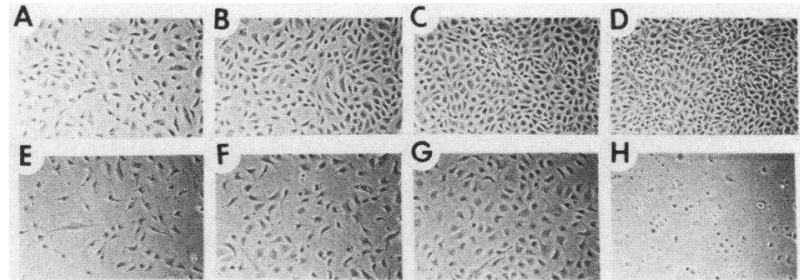

Figure 4 Morphological appearance of bovine vascular endothelial cells maintained on ECM-coated dishes and exposed to DMEM supplemented with $0.5 \%$ LPDS $(0.3 \mathrm{mg}$ protein $/ \mathrm{ml}$ ) and increasing concentrations of LDL (A, 25; B, 50; C, 100; and D, 250 $\mu \mathrm{g}$ protein/ml) or HDL (E, 50; F, 100; $\mathrm{G}, 250$; and $\mathrm{H}, 500 \mu \mathrm{g}$ protein $/ \mathrm{ml})$. Pictures were taken on day 6 (phase-contrast, $\times 100$ ).

medium did not survive. To test the possibility that HDL could prevent high concentrations of LDL from being toxic, cultures maintained in either $0.5,5$, or $10 \%$ LPDS-supplemented medium and exposed to LDL concentrations ranging from 500 to $800 \mu \mathrm{g}$ protein $/ \mathrm{ml}$ were also exposed to high HDL concentrations ranging from 500 to $2,000 \mu \mathrm{g}$ protein $/ \mathrm{ml}$ (Table II). In all cases, cells exposed to LDL alone died over a period of $6 \mathrm{~d}$ and addition of high concentrations of HDL did not rescue the cells. Similar results were observed when cultures maintained on ECM in the presence of serumfree medium were exposed to both toxic LDL concentrations (100 $\mu \mathrm{g}$ protein $/ \mathrm{ml}$ ) and high HDL concentrations ( $500 \mu \mathrm{g}$ protein $/ \mathrm{ml}$ ) (Table II). In contrast, HDL, even at concentrations as high as 1,200-2,000 $\mu \mathrm{g}$ protein $/ \mathrm{ml}$, optimally stimulated cell proliferation, provided that LDL was not added to the media (Table I). When cells were exposed to nontoxic concentrations of LDL (from 100 to $200 \mu \mathrm{g}$ proteins $/ \mathrm{ml}$ ) in the presence of 5 or $10 \%$ LPDS, cells grew normally, and addition of HDL at a concentration of $500 \mu \mathrm{g}$ protein $/ \mathrm{ml}$ did not significantly modify their growth rate (Table II). When cultures were maintained in LPDS-free medium and exposed to a mitogenic concentration of LDL (20 $\mu \mathrm{g}$ protein $/ \mathrm{ml}$ ), addition of HDL (500 $\mu \mathrm{g}$ protein $/ \mathrm{ml}$ ) greatly improved the growth rate of the cultures. This reflects the fact that in serum-free medium LDL, even at low concentration (above $30 \mu \mathrm{g}$ protein $/ \mathrm{ml}$ ), was shown to be cytotoxic. This greatly limits the concentration of LDL that one can add to the culture, and only a suboptimal growth rate can be sustained, thereby making possible a synergistic effect of HDL.

Culture lifetime of vascular endothelial cells maintained on an ECM in LPDS-supplemented medium and exposed to either LDL or HDL. Shown in Fig. 6 is a comparison of the culture lifetime of vascular endothelial cells passaged at low cell density on an ECM and exposed to optimal concentration of CS (10\%) with that of cultures maintained and passaged under similar conditions but exposed instead to 5\% LPDS and to medium supplemented with either LDL or HDL. Cultures maintained on ECM and exposed to CS alone were capable of undergoing 50 generations in the absence of FGF (Fig. 6A). Similar cultures exposed to LPDS and LDL ( $100 \mu \mathrm{g}$ protein $/ \mathrm{ml}$ ) underwent 38 generations, after which the cells senesced (Fig. 6B). In contrast, when exposed to LPDS alone, the cell hardly proliferated and went at most through three generations. When cultures were maintained in LPDS and HDL ( $500 \mu \mathrm{g}$ protein $/ \mathrm{ml}$ ), they underwent 41 generations, after which cells senesced (Fig. 6C). These results therefore demonstrate that either HDL or LDL can support the long-term growth of vascular endothelial cells and that their lifespan in culture is similar to, although slightly shorter than, that of cultures exposed to calf serum. However, one should keep in mind that in the case of LDL this result can only be achieved when cells are exposed to low LDL concentration (100 $\mu \mathrm{g}$ protein $/ \mathrm{ml}$ ), since concentrations of LDL approaching its physiological concentration $(600-800 \mu \mathrm{g}$ protein $/ \mathrm{ml}$ ) caused cell death.

Comparison of the proliferation of vascular endothelial cell cultures maintained on a plastic substrate and exposed to either serum-supplemented

TABLE I

Effect of High Concentrations of HDL on Proliferation of Bovine Vascular Endothelial Cells Maintained on ECM

\begin{tabular}{|c|c|c|c|c|}
\hline $\begin{array}{c}\text { HDL } \\
\text { concentrations }\end{array}$ & DMEM & $\begin{array}{c}\text { DMEM } \\
+0.5 \% \text { LPDS }\end{array}$ & $\begin{aligned} & \text { DMEM } \\
+ & 5 \% \text { LPDS }\end{aligned}$ & $\begin{aligned} & \text { DMEM } \\
+ & 10 \% \text { LPDS }\end{aligned}$ \\
\hline$\mu g$ protein $/ m l$ & \multicolumn{4}{|c|}{ cells/3.5-mm dish } \\
\hline 500 & $9.1 \times 10^{5}$ & \multirow{3}{*}{$\begin{array}{r}1 \times 10^{6} \\
1.02 \times 10^{6}\end{array}$} & $1.1 \times 10^{6}$ & $1.1 \times 10^{6}$ \\
\hline 1,200 & & & & $1.05 \times 10^{6}$ \\
\hline 2,000 & $9.3 \times 10^{5}$ & & $1.07 \times 10^{6}$ & \\
\hline
\end{tabular}

Bovine vascular endothelial cells were seeded at $2 \times 10^{4}$ cells $/ 35-\mathrm{mm}$ dish on ECM-coated dishes and exposed to DMEM supplemented or not with concentrations of LPDS ranging from 0.5 to $10 \%$. HDL was added once (day 0 ) at the indicated concentrations. After $6 \mathrm{~d}$, cultures were trypsinized and cells counted. 


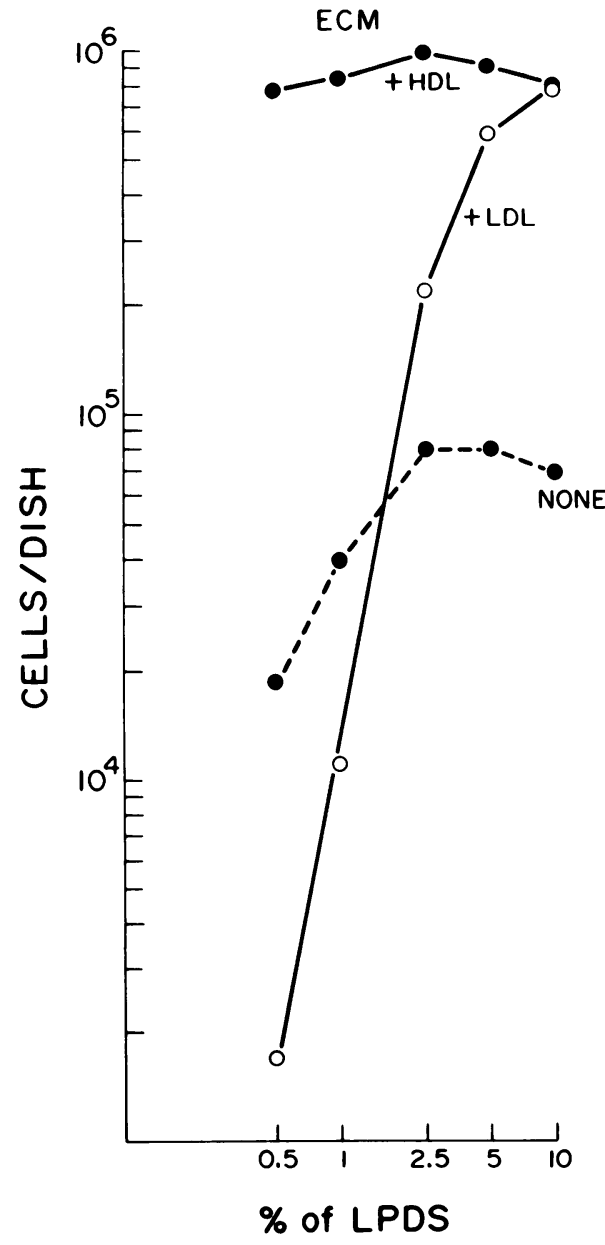

FIGURE 5 Effect of increasing concentrations of LPDS on the proliferative response of bovine vascular endothelial cells exposed to constant concentrations of LDL or HDL. Vascular endothelial cells were seeded at $2 \times 10^{4}$ cells $/ 35-\mathrm{mm}$ dish on ECM-coated dishes and exposed to DMEM supplemented with increasing concentrations, ranging from $0.5(0.3 \mathrm{mg} / \mathrm{ml})$ to $10 \%(6 \mathrm{mg} / \mathrm{ml})$, of LPDS $(---)$, increasing concentrations of LPDS plus $500 \mu \mathrm{g}$ protein/ml of HDL $(-\infty)$, or increasing concentrations of LPDS plus $200 \mu \mathrm{g}$ protein $/ \mathrm{ml}$ of LDL $(O-O)$. After $6 \mathrm{~d}$, cultures were trypsinized and counted.

medium or HDL-supplemented medium: the role of $F G F$. To determine whether vascular endothelial cell cultures maintained on plastic can respond to HDL and still require FGF to proliferate, low density cultures (20 cells $/ \mathrm{mm}^{2}$ ) maintained on plastic in total absence of serum were exposed to HDL-supplemented (500 $\mu \mathrm{g}$ protein $/ \mathrm{ml}$ ) medium and increasing concentrations of FGF. As shown in Fig. 7A, the rate of proliferation of such cultures was a strict function of the concentration of FGF to which cultures were exposed and was nearly maximal at an FGF concentration of $100 \mathrm{ng} / \mathrm{ml}$. When the rate of proliferation of such cultures was compared with that of cultures maintained in $10 \% \mathrm{CS}$, it was observed to be very similar (Fig. 7A). Cultures exposed to medium supplemented with CS had a proliferation rate that was a function of the FGF concentration to which they were exposed. Optimal cell proliferation was observed at an FGF concentration of $100 \mathrm{ng} / \mathrm{ml}$.

The morphological appearance of cultures exposed to optimal concentration of FGF (250 ng protein/ml) and variable concentrations of HDL is shown in Fig. 8A-E. At HDL concentrations ranging from 25 to $100 \mu \mathrm{g}$ protein/ml, cultures were still sparse (Fig. $8 \mathrm{~A}$ and $\mathrm{B}$ ) or subconfluent (Fig. 8C) after $6 \mathrm{~d}$. When exposed to HDL concentrations ranging from 250 to $500 \mu \mathrm{g}$ protein $/ \mathrm{ml}$, however, cultures became confluent within $6 \mathrm{~d}$ and adopted the configuration of a monolayer composed of tightly packed, small, and nonoverlapping cells (Fig. $8 \mathrm{~B}$ and $\mathrm{E}$ ). Likewise, cultures exposed to constant concentration of HDL (500 $\mu \mathrm{g}$ protein/ml) and variable concentrations of FGF (ranging from 0.1 to $10 \mathrm{ng} /$ $\mathrm{ml}$ ) still had, after $6 \mathrm{~d}$, the configuration of sparse (Fig. $8 \mathrm{~F}$ and $\mathrm{G}$ ) or subconfluent (Fig. 8H) cultures. Cultures became confluent within $6 \mathrm{~d}$ when exposed to concentrations of FGF ranging from 100 to $250 \mathrm{ng} / \mathrm{ml}$ (Fig.

\section{TABLE II}

Effect of HDL on the Proliferation of Vascular Endothelial Cell Cultures Exposed to Different Concentrations of LPDS and of $L D L$

\begin{tabular}{|c|c|c|c|c|}
\hline & $\mathrm{No}$ HDL & $\begin{array}{c}\text { HDL } \\
(500 \mu \mathrm{g} / \mathrm{ml})\end{array}$ & $\begin{array}{c}\text { HDL } \\
(1,200 \mu \mathrm{g} / \mathrm{ml})\end{array}$ & $\begin{array}{c}\text { HDL } \\
(2,0(0) \mu \mathrm{g} / \mathrm{ml})\end{array}$ \\
\hline & \multicolumn{4}{|c|}{ cells/35-mm dish } \\
\hline DMEM & & & & \\
\hline + LDL 20* & $0.9 \times 10^{5}$ & $8.8 \times 10^{5}$ & 一 & - \\
\hline DMEM & & & & \\
\hline+ LDL 100 & $0.3 \times 10^{3}$ & $2 \times 10^{3}$ & - & - \\
\hline $0.5 \% \mathrm{LPDS}$ & & & & \\
\hline+ LDL 500 & $0.4 \times 10^{3}$ & - & $1.1 \times 10^{3}$ & - \\
\hline $5 \%$ LPDS & & & & \\
\hline+ LDL 600 & $2.0 \times 10^{3}$ & - & - & $2.8 \times 10^{3}$ \\
\hline $10 \%$ LPDS & & & & \\
\hline + LDL 200 & $8.4 \times 10^{5}$ & $9.6 \times 10^{5}$ & - & - \\
\hline $10 \%$ LPDS & & & & \\
\hline + LDL 800 & $0.5 \times 10^{3}$ & $1.0 \times 10^{3}$ & - & - \\
\hline
\end{tabular}

Bovine vascular endothelial cells were seeded at $2 \times 10^{4}$ cells/ 35-mm dish on ECM-coated dishes and exposed to DMEM supplemented or not with concentrations of LPDS ranging from 0.5 to $10 \%$. HDL and/or LDL were added at the indicated concentrations. The concentrations of LDL that were chosen were mitogenic $(20 \mu \mathrm{g}$ protein $/ \mathrm{ml}$ in DMEM alone and $200 \mu \mathrm{g}$ protein $/ \mathrm{ml}$ in $10 \%$ LPDS-supplemented medium, respectively) or cytotoxic $(100,500,400$, and $800 \mu \mathrm{g}$ protein $/ \mathrm{ml}$ in DMEM alone, $0.5 \%$ LPDS, 5\% LPDS, and $10 \%$ LPDS-supplemented medium, respectively). After $6 \mathrm{~d}$, cultures were trypsinized and cells counted.

* Concentration of LDL added expressed as micrograms protein $/ \mathrm{ml}$. 


\section{VASCULAR ENDOTHELIAL CELLS}

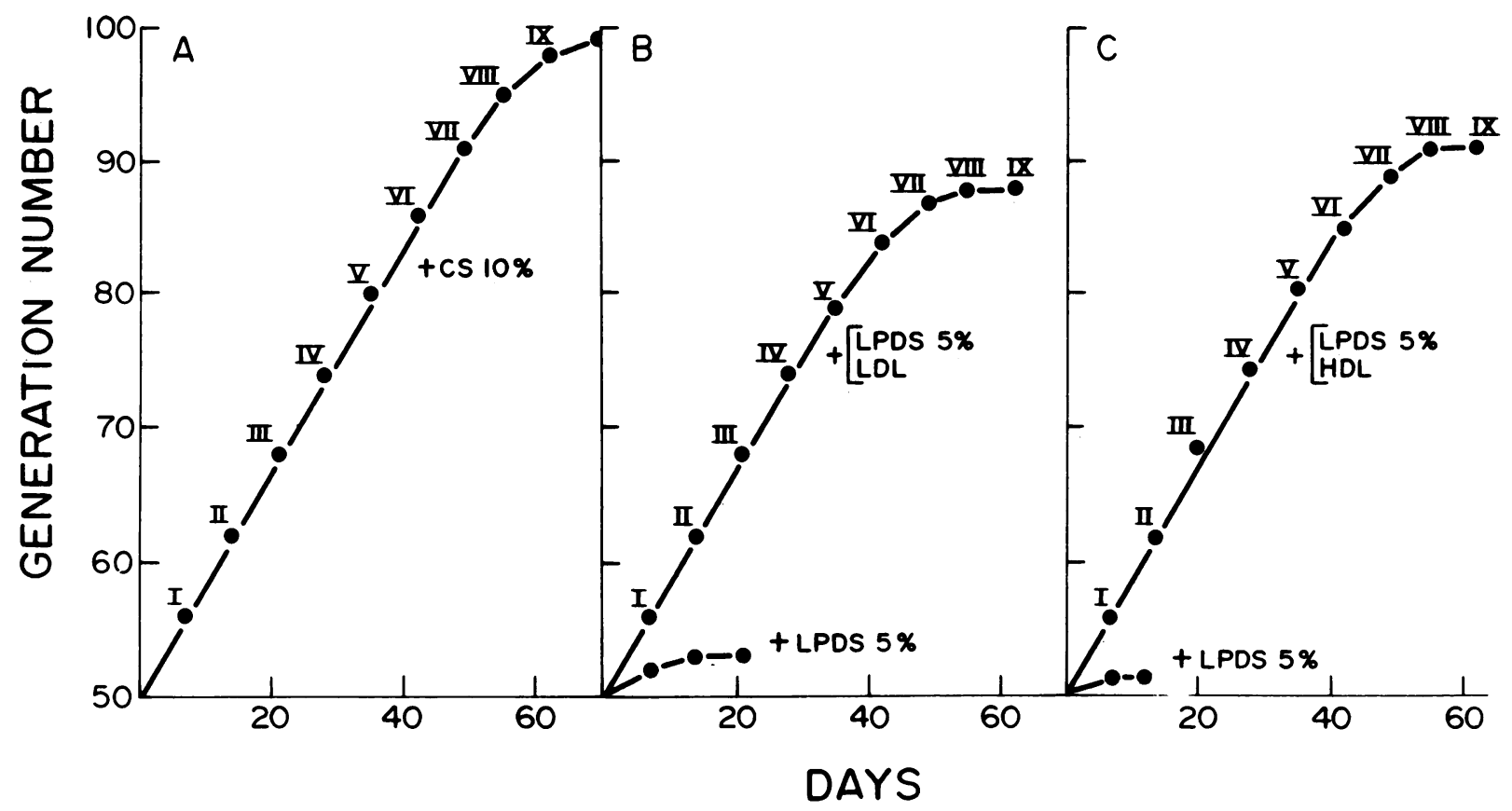

Figure 6 Culture lifetime of bovine vascular endothelial cells seeded on an ECM and exposed to $10 \% \mathrm{CS}, 5 \%$ LPDS, or 5\% LPDS supplemented with HDL or LDL. Vascular endothelial cells previously maintained on plastic tissue culture dishes and grown in the presence of DMEM supplemented with $10 \% \mathrm{CS}$ and FGF ( $100 \mathrm{ng} / \mathrm{ml}$ added every other day) for 50 generations were then maintained and passaged on dishes coated with an ECM without FGF and in the presence of DMEM supplemented with (A) $10 \% \mathrm{CS}$; (B) $5 \%$ LPDS with or without $100 \mu \mathrm{g}$ protein $/ \mathrm{ml}$ of LDL; or (C) $5 \%$ LPDS with or without $500 \mu \mathrm{g}$ protein $/ \mathrm{ml}$ of $\mathrm{HDL}$. The cells were seeded at $2 \times 10^{4}$ cells $/ 35-\mathrm{mm}$ dish and passaged every 6 or $7 \mathrm{~d}$. The number of generations was determined from the initial cell density $8 \mathrm{~h}$ after seeding and the number of cells harvested at each transfer. Each point represents a single transfer. Roman numerals indicate the passage number.

$8 \mathrm{I}-\mathrm{J})$. They adopted the configuration of a cell monolayer composed of tightly packed, small, and nonoverlapping cells. This therefore demonstrates that vascular endothelial cells maintained on plastic and exposed to HDL or to serum depend on FGF to proliferate at an optimal rate. Since similar rates of proliferation were observed when cultures maintained in the presence of FGF were exposed to either $10 \% \mathrm{CS}$ or $500 \mu \mathrm{g}$ protein/ml HDL (Fig. 7A), it also demonstrates that HDL can completely replace the requirement for serum to support active proliferation.

Comparison of the proliferation of vascular endothelial cell cultures exposed to increasing concentrations of HDL or LDL and maintained on plastic dishes in the presence of serum-free medium supplemented with FGF vs. that of cultures maintained on ECMcoated dishes and exposed to a serum-free medium supplemented with increasing concentrations of either $H D L$ or $L D L$. To demonstrate that cells maintained on ECM-coated dishes respond to HDL alone and no longer require $\mathrm{FGF}$ to proliferate, the mitogenic effects of increasing concentrations of HDL on cultures maintained on plastic and exposed to serum-free medium supplemented with FGF $(250 \mathrm{ng} / \mathrm{ml})$ vs. its effect on cultures maintained on ECM and exposed to serumfree medium alone (Fig. 7B) were compared. Low density (20 cells $/ \mathrm{mm}^{2}$ ) cultures maintained on plastic and exposed to serum-free medium and FGF, or maintained on ECM-coated dishes and exposed to serumfree medium alone, did not proliferate unless HDL was added to the medium. The rate of proliferation was a strict function of the concentration of $\mathrm{HDL}$ to which cultures were exposed and was the same regardless of whether or not cultures were maintained on plastic and exposed to FGF, or maintained on ECM and not exposed to FGF. As observed earlier, in both cases a nearly maximal proliferative rate was observed at an HDL concentration of 500 $\mu \mathrm{g}$ protein $/ \mathrm{ml}$. The morphological appearance of such cultures is shown in Fig. 8K-O. Cultures maintained on ECM and exposed to HDL concentrations ranging from 25 to $100 \mu \mathrm{g}$ protein $/ \mathrm{ml}$ still had a sparse or sub- 

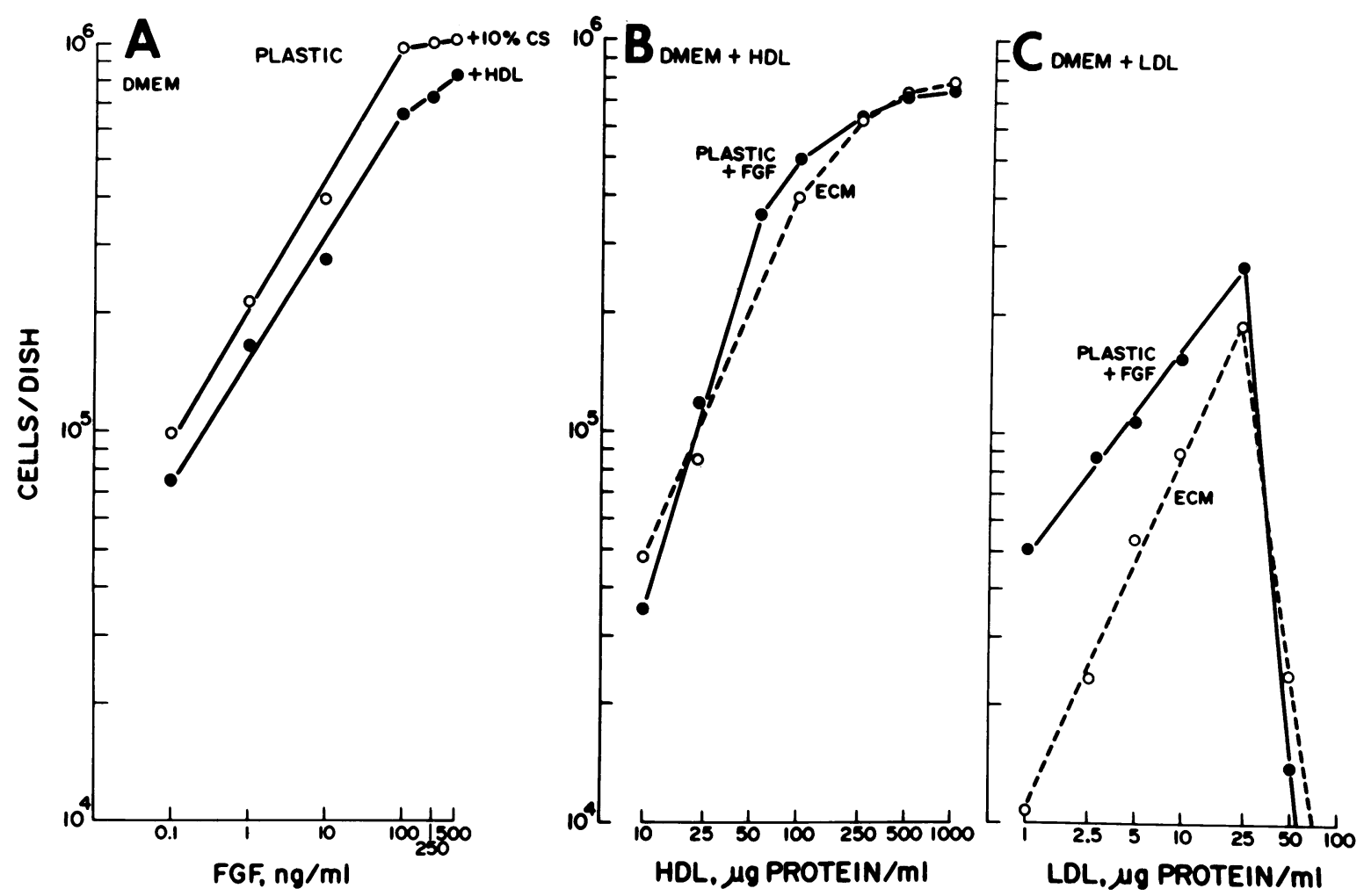

FIGURE 7 Comparison of the proliferation of bovine vascular endothelial cell cultures maintained on plastic and exposed to either $10 \%$ CS or serum-free medium supplemented with HDL (500) $\mu \mathrm{g}$ protein $/ \mathrm{ml}$ ) and increasing concentrations of FGF (A) vs. that of cultures maintained either on plastic or ECM-coated dishes and exposed to serum-free medium supplemented with either increasing concentrations of HDL (B) or LDL (C). (A) Vascular endothelial cells were seeded at $2 \times 10^{4}$ cells $/ 35-\mathrm{mm}$ plastic dish and exposed to medium supplemented with either $10 \% \mathrm{CS}(\mathrm{O})$ or $500 \mu \mathrm{g}$ protein $/ \mathrm{ml}$ of HDL (๑). FGF was added every other day at concentrations ranging from 0.1 to $500 \mathrm{ng} / \mathrm{ml}$. After $6 \mathrm{~d}$, cell cultures were trypsinized and counted. (B and C) Vascular endothelial cells were seeded at $2 \times 10^{4}$ cells/35-mm dish in $10 \%$ CS in either plastic (O) or ECMcoated $(O)$ dishes. $8 \mathrm{~h}$ later, medium was removed and the cultures washed twice. Serum-free medium supplemented with increasing concentrations of HDL (from 10 to $1,000 \mu \mathrm{g} p \mathrm{potein} / \mathrm{ml}$ ) (B) or with increasing concentrations of LDL (C) ( 10 to $100 \mu \mathrm{g}$ protein/ml) was then added. When cultures were maintained on plastic, FGF $(100 \mathrm{ng} / \mathrm{ml})$ was added every other day. On day 6 the cultures were trypsinized and the cells counted.

confluent morphology after $6 \mathrm{~d}$ in culture (Fig. 8K-M). When exposed to HDL concentrations of $250-500 \mu \mathrm{g}$ protein $/ \mathrm{ml}$, the cultures became confluent within $6 \mathrm{~d}$ and their morphological appearance was similar to cultures maintained on plastic and exposed to optimal concentrations of both FGF and HDL (Fig. 8E and J). That cultures maintained on ECM-coated dishes no longer require FGF to respond to HDL substantiates earlier findings (1) that cells maintained on ECM no longer require FGF to respond to plasma factors such as HDL.

In contrast to HDL, concentrations of LDL $>25 \mu \mathrm{g}$ protein $/ \mathrm{ml}$ were toxic for the cells, even when cells were maintained on plastic and exposed to serum-free medium supplemented with FGF or on ECM-coated dishes and exposed to serum-free medium alone (Fig.
7C). The only noticeable difference between the two culture conditions was that cells maintained on plastic in serum-free medium and FGF survived better when exposed to low concentrations of LDL ( $1-25 \mu \mathrm{g}$ proteins $/ \mathrm{ml}$ ) than when cells were maintained on EC.Mcoated dishes.

The morphological appearance of cultures maintained on ECM and exposed to increasing concentrations of LDL (1-50 $\mu \mathrm{g}$ protein/ml) is shown in Fig. 8P-T). Cells exposed to high concentrations of LDL (50 $\mu \mathrm{g}$ protein $/ \mathrm{ml}$, Fig. $8 \mathrm{~T}$ ) died over a period of $6 \mathrm{~d}$. When cells were exposed to lower LDL concentrations (1-25 $\mu \mathrm{g}$ protein/ml, Fig. 8P-S), they looked unhealthy, greatly enlarged, and vacuolated, and in no case did the cultures become confluent within $6 \mathrm{~d}$. This cytotoxic effect of LDL in serum-free medium is simi- 


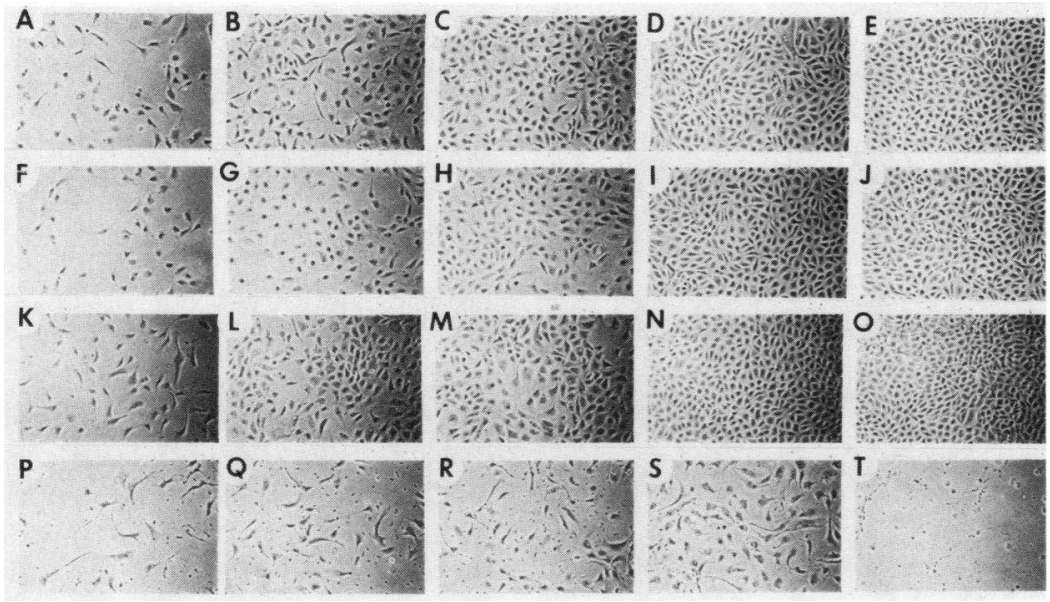

Figure 8 Morphological appearance of bovine vascular endothelial cell cultures maintained either in plastic dishes $(\mathrm{A}-\mathrm{J})$ or ECM-coated dishes $(\mathrm{K}-\mathrm{T})$. Cells were exposed to DMEM supplemented with increasing concentrations of HDL ( $\mathrm{A}$ and $\mathrm{K}, 25 ; \mathrm{B}$ and $\mathrm{L}, 50$; $\mathrm{C}$ and $\mathrm{M}, 100$; $\mathrm{D}$ and $\mathrm{N}, 25()$; and $\mathrm{E}$ and $\mathrm{O}, 500 \mu \mathrm{g}$ protein $/ \mathrm{ml})$, DME.M supplemented with $500 \mu \mathrm{g}$ protein $/ \mathrm{ml}$ of HDL $(\mathrm{F}-\mathrm{J})$, or DMEM supplemented with increasing concentrations of LDL $(\mathrm{P}, 1 ; \mathrm{Q}, 5 ; \mathrm{R}, 10 ; \mathrm{S}, 25$; $\mathrm{T}, 50 \mu \mathrm{g}$ protein $/ \mathrm{ml})$. In the case of plastic dishes, FGF was added every other day at different concentrations ( F, 0.1; G, 1.0; H, 10; I, 100 g; and A-E, J, 250 ng/ml). Pictures were taken on day 6 (phase-contrast, $\times 100$ ).

lar to that already observed when cells were maintained on EC.M and exposed to medium supplemented with either low or high LPDS concentrations (Fig. 3A and B).

The cytotoxic effect of LDL obviously limits the concentration of LDL to which cultures can be exposed. This results in a much lower growth rate when cultures are exposed to LDL than when they are exposed to HDL. As shown in Fig. 9, cultures seeded at 20 cells/ $\mathrm{mm}^{2}$ on dishes coated with an ECM and exposed to serum-free medium reached confluence $(1,000$ cells/ $\mathrm{mm}^{2}$ ) within $6 \mathrm{~d}$, provided that HDL ( $500 \mu \mathrm{g}$ protein/ $\mathrm{ml}$ ) was present in the medium. The average doubling time of the cultures during their logarithmic growth phase was $24 \mathrm{~h}$. Similar cultures exposed to LDL (30) $\mu \mathrm{g} / \mathrm{ml}$ ) did not reach confluence within $6 \mathrm{~d}$ and their final density was 250 cell $\mathrm{s} / \mathrm{mm}^{2}$. The average doubling time of the cultures during their logarithmic growth phase was $39 \mathrm{~h}$. When exposed to $80 \mu \mathrm{g}$ protein $/ \mathrm{ml}$ LDL, the cells died (Fig. 9).

\section{DISCUSSION}

The present results demonstrate that vascular endothelial cells maintained in the presence of medium supplemented with LPDS require the presence of lipoproteins in order to proliferate optimally. Of the two classes of lipoproteins (HDL and LDL) that have been studied, HDL seems to be the major factor involved in the proliferation of vascular endothelial cells. This is mostly due to its lack of toxicity when added at high concentration, as well as to its nondependence on
LPDS to exhibit its mitogenic properties. The mitogenic effect induced by HDL alone seems to be unique to vascular endothelial cells. Four other cell types have been tested thus far in our laboratory, including granulosa, adrenal cortex, corneal endothelial, and vascular smooth muscle cells. Addition of HDL alone to such cultures maintained on ECM-coated dishes and exposed to serum-free medium had little or no effect. To induce optimal proliferation, all four cell types required, in addition to HDL, insulin (which can be replaced by somatomedin C). In the case of granulosa, corneal endothelial, and vascular smooth muscle cells, EGF was also required $(24-26) .^{5}$

One of the unexpected results of the present study is that LDL, even at concentrations far below its in vivo physiological range, proved toxic for vascular endothelial cells. A similar observation has been made by Henriksen et al. $(27,28)$ in the case of cultured human endothelial cells derived from the umbilical vein. Although this could reflect an LDL sensitivity peculiar to vascular endothelial cells, it is not likely. Other cultured cell types, such as vascular smooth muscle cells of various species (6-9), as well as established cell lines such as lymphoma or chinese hamster ovary cells (10), have been shown to respond to LDL with an increased proliferative rate. However, in all cases

\footnotetext{
"Gospodarowicz, D., K. Hirabayashi, L. Giguiere, and J-P. Tauber. Control of proliferation of vascular smooth muscle cells by high and low density lipoproteins, insulin, and by fibroblast and epidermal growth factors. Submitted for publication.
} 


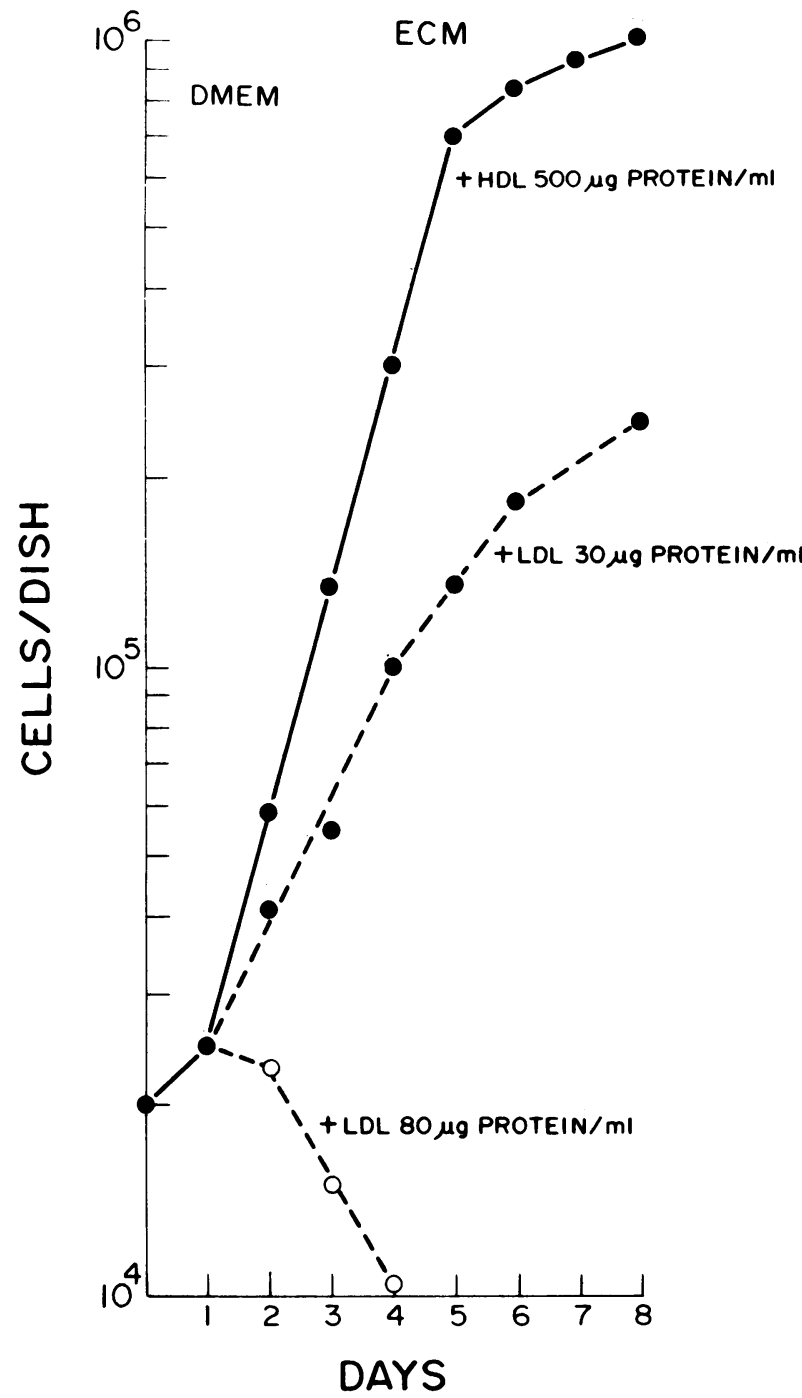

FIGURE 9 Proliferative rate of bovine vascular endothelial cells maintained on ECM-coated dishes and exposed to DMEM supplemented with either HDL or LDL. Vascular endothelial cells were seeded at $2 \times 10^{4}$ cells $/ 35-\mathrm{mm}$ dish on ECM-coated dishes and exposed to DMEM supplemented with $10 \%$ calf serum. $6 \mathrm{~h}$ later, the medium was removed and cultures washed twice. DMEM supplemented with $500 \mu \mathrm{g}$ protein $/ \mathrm{ml}$ of $\mathrm{HDL}(\mathrm{O}-\mathrm{O}), 30 \mu \mathrm{g}$ protein $/ \mathrm{ml}$ of $\mathrm{LDL}$ (- - - $)$, or $80 \mu \mathrm{g}$ protein $/ \mathrm{ml}$ of LDL $\left(\mathrm{O}_{--} \mathrm{O}^{-}\right.$) was then added. Triplicate plates representing each condition were trypsinized and counted every day.

these studies were done with cells exposed to high LPDS concentrations and low LDL concentrations (10-50 $\mu \mathrm{g}$ protein $/ \mathrm{ml})$. Under these conditions, LDL would not be expected to show its cytotoxic effect, since this can only be observed at concentrations $>200 \mu \mathrm{g}$ protein $/ \mathrm{ml}$, when cells are exposed to high (10\%) LPDS concentration.

It has been pointed out by Goldstein and Brown (29) that, in all human cells studied thus far (i.e., fibroblasts, arterial smooth muscle, and lymphoid cells), the LDL receptor is capable of supporting cell growth and keeps HMG coenzyme A reductase suppressed when the lipoprotein is present at a level of $15 \mu \mathrm{g}$ protein $/ \mathrm{ml}(29)$. In view of the 10 -fold gradient in LDL concentration between plasma and lymph or interstitial fluid (30), Goldstein and Brown (29) have suggested that the appropriate level of plasma LDL concentration should be $150 \mu \mathrm{g}$ protein $/ \mathrm{ml}$. This is exactly the range of concentration within which we observed the full mitogenic potential of LDL. In contrast, concentration fivefold higher corresponding to the LDL protein concentration normally present in human plasma is cytotoxic for low density vascular endothelial cell cultures. It is also quite significant that the appropriate plasmatic level of LDL protein predicted by Goldstein and Brown is, as they observed (29), the same as that measured in eight other mammalian species that do not suffer atherosclerosis (31) and is similar to the mean level of LDL protein observed in humans newly born (32), a time at which the vascular endothelium has completed its formation.

The observation that HDL no longer stimulates the proliferation of vascular endothelial cells already exposed to high and toxic concentrations of LDL was to be expected, since we have observed ${ }^{2,3}$ that, although HDL competes poorly with LDL for LDL receptor sites, LDL will compete strongly for HDL receptor sites, a competition that can eventually result in the inability of HDL to play its role as a mitogen. The toxicity of LDL at high concentration is a function of cell density. While at low density, cells exposed to high LDL concentration rapidly died, but when cells were confluent, LDL even at a physiological level (600-800 $\mu \mathrm{g}$ protein $/ \mathrm{ml}$ ) was no longer toxic (33). However, under these conditions cells were contact inhibited and no longer divided. One is therefore faced with a totally different situation, and the lack of toxicity of LDL in contact-inhibited cultures may be explained by its greatly reduced rate of internalization (4). A critical experiment would be to see whether high LDL concentration impedes cell migration and proliferation when a wound is made in the monolayer, thereby limiting the repair process of the vascular endothelium. Indeed, when the effects of HDL and LDL on the repair process of wounded confluent monolayers of vascular endothelial cells exposed to an LPDS-supplemented medium were analyzed, it was found that the addition of HDL to the medium leads to a rapid repair process. In contrast, LDL added at high concentration adversely affects the repair process of the endothelium (33).

The protective effect of high LPDS concentration when cells are exposed to LDL is unexplained. It is likely that one or more factors will be found in LPDS that can protect the cells against the cytotoxic effect of LDL. The relationship between LDL's mitogenic effect and the 
amount of LPDS to which vascular endothelial cells are exposed suggests that, in the absence of HDL, one or more additional components from the serum are necessary for endothelial cell growth.

Factors that in vivo influence and control the repair process of the endothelium following injury are still unknown. If it were to be demonstrated that HDL and LDL have effects in vivo similar to those observed in vitro, this would raise the questions of the eventual positive effect of HDL in endothelial cell repair and of LDL as a negative factor in that process.

\section{ACKNOWLEDGMENTS}

The authors wish to thank Mr. Harvey Scodel for his invaluable help in the preparation of this manuscript.

This work was supported by grant HL 23638 from the National Institutes of Health.

\section{REFERENCES}

1. Gospodarowicz, D., and C. R. Ill. Extracellular matrix and control of proliferation of vascular endothelial cells. J. Clin. Invest. 65: 1351-1364.

2. Stein, O., and Y. Stein. 1976. High density lipoproteins reduce the uptake of low density lipoproteins by human endothelial cells in culture. Biochim. Biophys. Acta. 23: $563-568$.

3. Reckless, J. P. D., D. B. Weinstein, and D. Steinberg. 1978. Lipoprotein and cholesterol metabolism in rabbit arterial endothelial cells in culture. Biochim. Biophys. Acta. 529: 475-487.

4. Vlodavsky, I., P. E. Fielding, C. J. Fielding, and D. Gospodarowicz. 1978. Role of contact inhibition in the regulation of receptor-mediated uptake of low density lipoprotein in cultured vascular endothelial cells. Proc. Natl. Acad. Sci. U. S. A. 75: 356-360.

5. Fielding, P. E., I. Vlodavsky, D. Gospodarowicz, and C. J. Fielding. 1979. Effect of contact inhibition on the regulation of cholesterol metabolism in cultured vascular endothelial cells. J. Biol. Chem. 254: 749-755.

6. Ross, R., and J. A. Glomset. 1973. A therosclerosis and the arterial smooth muscle cells. Science (Wash. D. C.). 180: $1332-133$.

7. Brown, G., R. Mahley, and G. Assmann. 1976. Swine aortic smooth muscle cells in tissue culture. Some effect of purified swine lipoproteins on cell growth and morphology. Circ. Res. 39: 415-424.

8. Fischer-Dzoga, K., R. Fraser, and R. W. Wissler. 1976. Stimulation of proliferation in stationary primary cultures of monkey and rabbit aortic smooth muscle cells. I. Effects of lipoprotein fractions of hyperlipemic serum and lymph. Exp. Mol. Pathol. 24: 346-359.

9. Layman, D. L., B. J. Jelen, and D. R. Illingworth. 1980. Inability of serum from abetalipoproteinemic subjects to stimulate proliferation of human smooth muscle cells. Proc. Natl. Acad. Sci. U. S. A. 77: 1511-1515.

10. Goldstein, J. L., J. A. S. Helgeson, and M. S. Brown. 1979. Inhibition of cholesterol synthesis with compactin renders growth of cultured cells dependent on the low density lipoprotein receptors. J. Biol. Chem. 254: 54035409.

11. Gospodarowicz, D., H. Bialecki, and G. Greenburg. 1978. Purification of the fibroblast growth factor activity from bovine brain. J. Biol. Chem. 253: 3736-3744.

12. Ross, R., J. Glomset, B. Kariya, and L. Harker. 1974. A platelet-dependent serum factor that stimulates the proliferation of arterial smooth muscle cells in vitro. Proc. Natl. Acad. Sci. U. S. A. 71: 1207-1210.

13. Ross, R., C. Nist, B. Kariya, M. J. Rivest, E. Raines, and J. Callis. 1978. Physiological quiescence in plasma-derived serum: influence of platelet-derived growth factor on cell growth in culture. J. Cell Physiol. 97: 497-508.

14. Maxwell, M. A. K., S. M. Hars, L. L. Bieber, and N. E. Tolbert. 1978. A modification of the Lowry procedure to simplify protein determination in membrane and lipoprotein samples. Anal. Biochem. 87: 206-210.

15. Lowry, O. H., N. J. Rosebrough, A. L. Faar, and J. Randall. 1951. Protein measurement with the Folin phenol reagent. J. Biol. Chem. 193: 263-275.

16. Havel, R. J., H. S. Eder, and J. A. Bragdon. 1955. The distribution and chemical composition of ultracentrifugally separated lipoprotein in human serum. J. Clin. Invest. 34: 1345-1353.

17. Gospodarowicz, D., A. L. Mescher, and C. R. Birdwell. 1977. Stimulation of cornea endothelial cell proliferation in vitro by fibroblast and epidermal growth factors. Exp. Eye Res. 25: 75-87.

18. Gospodarowicz, D., and G. Greenburg. 1978. The coating of bovine and rabbit comeas denuded of their endothelium with bovine corneal endothelial cells. Exp. Eye Res. 28: 249-265.

19. Vlodavsky, I., G. M. Lui, and D. Gospodarowicz. 1980. Morphological appearance, growth behavior, and migratory activity of human tumor cells maintained on extracellular matrix versus plastic. Cell. 19: 607-616.

20. Gospodarowicz, D., D. Delgado, and I. Vlodavsky. 1979. Control of cell proliferation in vitro by the extracellular matrix. Proc. Natl. Acad. Sci. U.S.A. 77: 4094-4098.

21. Gospodarowicz, D., J. Moran, D. Braun, and C. R. Birdwell. 1976. Clonal growth of bovine endothelial cells in tissue culture: fibroblast growth factor as a survival agent. Proc. Natl. Acad. Sci. U. S. A. 73: 4120-4124.

22. Gospodarowicz, D., J. Moran, and D. Braun. 1977. Control of proliferation of bovine vascular endothelial cells. $J$. Cell. Physiol. 91 : 377-38.5.

23. Gospodarowicz, D., G. Greenburg, H. Bialecki, and B. Zetter. 1978. The role of fibroblast and epidermal growth factor in the proliferative response of mammalian cells. In Vitro (Rockville). 14: 85-118.

24. Gospodarowicz, D., J. Cheng, K. Hirabayashi, and J-P. Tauber. The extracellular matrix and the control of vascular endothelial and smooth muscle cell proliferation in cellular interactions. In Research Monographs in Cell and Tissue Physiology, North-Holland Publishing Co., Amsterdam, The Netherlands. 7: in press.

25. Gospodarowicz, D. Growth control of mammalian cells. Growth factors and extracellular matrix in the biology of normal human growth. Proceedings of the First Karolinska Institute Nobel Conference. Raven Press, New York. In press.

26. Gospodarowicz, D., and I. Vlodvasky. 1981. The role of the extracellular matrix and growth factors in the control of proliferation of anchorage-dependent cells. Prog. Cancer Res. Ther. In press.

27. Henriksen, T., S. A. Evensen, and B. Carlender. 1979. Injury to human endothelial cells in culture induced by low density lipoproteins. Scand. J. Clin. Lab. Invest. 39: 361-368.

28. Henriksen, T., S. A. Evensen, and B. Carlender. 1979. Injury to cultured endothelial cells induced by low density lipoproteins: protection by high density lipoproteins. Scand. J. Clin. Lab. Invest. 39: 369-375.

29. Goldstein, J. L., and M. S. Brown. 1977. The low-density 
lipoprotein pathway and its relation to atherosclerosis. Annu. Rev. Biochem. 46: 897-930.

30. Reichl, D., L. A. Simons, N. B. Myang, J. J. Pflug, and G. L. Mills. 1973. The lipids and lipoproteins of human peripheral lymph, with observations on the transport of cholesterol from plasma and tissues into lymph. Clin. Sci. Mol. Med. 45: 313-329.

31. Mills, G. L., and C. E. Taylaur. 1971. The distribution and composition of serum lipoproteins in eighteen animals.
Comp. Biochem. Physiol. B. Comp. Biochem. 40: 489501.

32. Tsang, R. C., C. J. Glueck, R. W. Fallat, and M. Mellies. 1975. Neonatal familial hypercholesterolemia. Am.J. Dis. Child. 129: 83-91.

33. Tauber, J-P., and D. Gospodarowicz. 1980. Effects of high and low density lipoproteins on the repair process of wounded endothelial cell cultures. J. Cell. Physiol. In press. 